\title{
Protein-induced satiation and the calcium-sensing receptor
}

This article was published in the following Dove Press journal: Diabetes, Metabolic Syndrome and Obesity:Targets and Therapy

\section{Utkarsh Ojha}

Faculty of Medicine, Imperial College School of Medicine, Imperial College London, London, UK
Correspondence: Utkarsh Ojha Faculty of Medicine, Imperial College School of Medicine, Sir Alexander Fleming Building, Imperial College London, Exhibition Road, London SW7 2AZ, UK

Tel +447759667685

Email utkarsh.ojhal3@imperial.ac.uk

\begin{abstract}
Obesity is a major global health issue. High-protein diets have been shown to be associated with weight loss and satiety. The precise mechanism by which protein-rich diets promote weight loss remains unclear. Evidence suggests amino acids, formed as a consequence of protein digestion, are sensed by specific receptors on L-cells in the gastrointestinal (GI) tract. These L-cells respond by secreting gut hormones that subsequently induce satiety. In recent years, the calcium-sensing receptor has been identified in several cells of the GI tract, including L-cells, and suggested to sense specific amino acids. This review evaluates the evidence for protein-rich diets in inducing weight loss and how the calcium-sensing receptor may be implicated in this phenomenon. Commandeering the mechanisms by which elements of a protein-rich diet suppress appetite may provide another successful avenue for developing anti-obesity drugs. Keywords: amino acids, energy regulation, obesity therapy, glucagon-like-peptide-1, peptide YY
\end{abstract}

\section{Introduction}

According to the 2014 report from the World Health Organization, ${ }^{1} 600$ million people worldwide are classified as obese, a figure which has more than doubled over the last 2 decades. The sharp rise in obesity has primarily been attributed to the availability of cheap, high-energy foodstuffs, and low physical activity, resulting in a positive energy balance. Obesity is an established risk factor for cardiovascular disease and type 2 diabetes mellitus. ${ }^{2}$ The rising prevalence of psychological and social issues associated with obesity has increased the demand for successful anti-obesity treatments. First-line management plans often include changes to diet and lifestyle, ${ }^{3}$ but these have little long-term benefits since they are typically difficult to adhere to. Currently, the most effective treatment for large and sustained weight loss is bariatric surgery. ${ }^{4}$ However, due to its invasive nature and high cost, this procedure is limited to morbidly obese patients.

The central control of energy intake is primarily linked to the hypothalamus and brainstem. Several drugs have aimed to reduce appetite by targeting neurotransmitters and neurons in these areas of the brain. Since these signaling molecules do not exclusively regulate appetite, obesity drugs have often led to adverse side effects. ${ }^{5-7}$ Efficacy and safety concerns present significant barriers to obtaining marketing approval, which is reflected by the relatively small valuation of the obesity drug market. ${ }^{8}$ Orlistat, a gastric and pancreatic lipase inhibitor, is the only prescription medicine for obesity that is licensed and marketed in the UK to date. However, side effects of Orlistat such as fecal incontinence have led to poor patient compliance. ${ }^{9}$ 


\section{The gut-brain axis (GBA)}

It is now known the gastrointestinal (GI) tract regulates appetite by communicating with the brain. This bidirectional communication between the GI tract and the brain gives rise to the GBA. Peripheral hormones from the GI tract send information to the brain about the body's nutritional state and adiposity either directly or via the vagus nerve. The signals from these hormones are integrated further with higher brain center signals to regulate energy homeostasis (Figure 1).

The enteroendocrine cells (EEC) constitute a critical component of the GBA. Derived from multipotent stem cells toward the base of the intestinal crypts, EEC secrete various peptides. Immunohistochemical ${ }^{10}$ and fluorescence-activated cell-sorted studies ${ }^{11}$ demonstrate that EEC often express 2 or more products. The glucagon-like peptide-1 (GLP-1) and peptide tyrosine tyrosine (PYY) co-expressing enteroendocrine L-cells are believed to be involved in the regulation of energy omeostasis. PYY is a 36 amino acid peptide that belongs to the pancreatic polypeptide-fold family. PYY has 2 forms: PYY ${ }_{1-36}$ and PYY ${ }_{3-36}{ }^{12}$ Enzymatic cleavage of PYY ${ }_{1-36}$ by dipeptidyl peptidase IV gives rise to $\mathrm{PYY}_{3-36}$, the more abundant form, in the postprandial state. ${ }^{13} \mathrm{GLP}-1$ is synthesized from its precursor preproglucagon. Physiological action of GLP-1 includes suppressing endogenous glucose production by stimulating insulin secretion and inhibiting glucagon release. GLP-1 and PYY have also been shown to contribute to the short-term feeling of satiety and hunger. Intracerebroventricular administration of GLP- $1^{14}$ and intra-arcuate injection of PYY ${ }_{3-36}^{15}$ in rodents potently decreases food intake and body weight. These gut hormones further regulate the inhibitory feedback mechanism controlling intestinal transit and can therefore also induce satiety by prolonging gastric distention. ${ }^{16-18}$

Enteroendocrine L-cells are located along the GI tract, with their density increasing in the distal small intestine. ${ }^{19}$

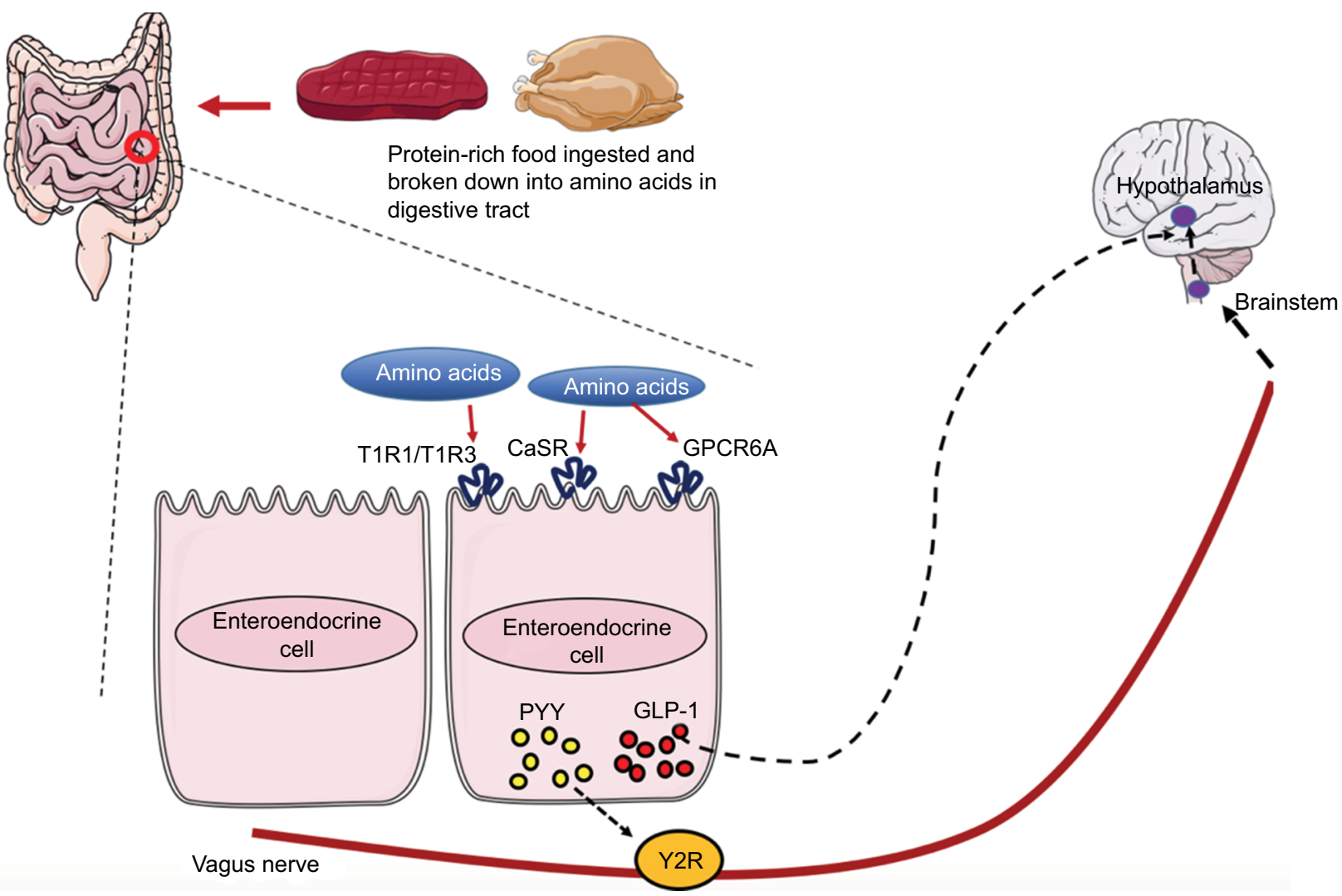

Figure I Gut-brain axis: consequence of amino acid sensing by receptors on the EEC.

Notes: Following sensing of amino acids by receptors on the EEC, peptides such as GLP-I and PYY are secreted from the EEC and regulate food intake by binding to their respective receptors. PYY binds to Y2R located on the vagus nerve fiber terminals, which signals to the brain stem and eventually the hypothalamus. GLP-I can pass through the blood and act directly at GLP-I receptors in the hypothalamus and exert its effects on satiety. The hypothalamus has a collection of nuclei (not shown in Figure I); the ARC is a collection of neurons in the mediobasal hypothalamus, and is thought to be implicated in the control of food intake. The ARC contains two populations of neurons with opposing effect on food intake. The agouti-related peptide/neuropeptide $Y$ neurons stimulate food intake, whereas pro-opiomelanocortin neurons suppress appetite. The ARC also sends numerous projections to both extra- and intra-hypothalamic regions responsible for energy homeostasis, including the paraventricular nucleus. Further connections are formed between these populations of neurons and higher brain centers.

Abbreviations: ARC, arcuate nucleus; CaSR, calcium-sensing receptor; EEC, enteroendocrine cells; GLP-I, glucagon-like peptide-I; GPRC6A, G-protein-coupled receptor family C group 6-member A; PYY, peptide tyrosine tyrosine; TIR, taste receptor I; Y2R, Y2 receptors. 
Following secretion from L-cells, GLP-1 and PYY diffuse into the lamina propria and reach the systemic circulation via the hepatic portal vein. Studies in humans show that systemic circulating concentrations of both hormones increase within 15 minutes of food ingestion. ${ }^{15,20}$ In the fasting state, GLP-1 and PYY circulate at low, basal levels. These levels increase sharply postprandially, approximately proportionately to calories ingested. ${ }^{15}$ Subcutaneous administration of GLP- $1^{21}$ or PYY ${ }_{3-36}^{22}$ have been reported to reduce appetite in humans. These observations further support the evidence that GLP-1 and PYY act as anorectic peptides. In addition to this physiological role, the weight-reducing effects of bariatric surgery have been linked to increased circulating GLP-1 and PYY levels. In Pyy null mice, the acute effects of gastric bypass on reducing body weight are diminished. ${ }^{23}$ However, wildtype mice losing body weight post-bypass surgery display elevated colonic PYY and circulating fasting PYY levels. In humans, meal-induced GLP-1 levels are elevated only days after bariatric surgery, and remain elevated for at least a decade. ${ }^{24}$ Moreover, inhibiting gut hormone release in humans with Octreotide, a somatostatin analog, attenuates the reduction in food intake after gastric bypass. ${ }^{25}$ Targeting these gut hormones themselves or their receptors has revealed promising results in the management of body weight; the GLP-1 receptor agonist Liraglutide (Saxenda) was recently approved by both the European Commission ${ }^{26}$ and the US Food and Drug Administration ${ }^{27}$ as an anti-obesity drug.

\section{High-protein diet promotes weight loss}

A growing body of evidence suggests that a high-protein diet promotes satiety and weight loss. Early studies by Skov et $\mathrm{al}^{28}$ demonstrated that dietary protein may by implicated in body weight management. The authors randomly assigned 65 healthy, overweight and obese subjects to a highcarbohydrate, high-protein and control diet for 6 months. Results showed that weight loss was greatest amongst participants on the high-protein diet. Further investigations ${ }^{29,30}$ have compared the effects of energy-restricted diets to protein-rich diets. These studies predominantly show that both energy restriction and protein-rich diets lead to significant weight loss but high-protein diets yield a greater reduction in fat mass and greater preservation of fat-free mass. Modest weight loss such as $5 \%-10 \%$ of total body weight can have several health benefits. However, to maintain this improved health, it is critical to sustain the weight loss over the long term. Westerterp-Plantenga et $\mathrm{al}^{31}$ demonstrated that diets rich in protein can limit weight gain following significant weight loss. This study involved 148 subjects who followed a low-energy diet for 4 weeks. Following this energy-restriction diet, participants were given either a normal- or high-protein diet. The additional protein intake led to a lower percentage of weight regain compared to the normal-protein diet. The satiating effects of protein have been linked to gut hormone secretion. In a study by Batterham et al, ${ }^{32}$ adults were fed a high-protein meal and 2 low-protein meals rich in either fat or carbohydrate. The results revealed that in normal-weight and obese subjects, a high-protein diet induced the greatest release of PYY. The study also tested Pyy null mice. The authors reported that Pyy null mice were resistant to the weight-reducing effects of a high protein diet and developed marked obesity. This effect was reversed following exogenous PYY treatment. Lejeune et $\mathrm{al}^{33}$ assessed several mechanisms of satiety during a high-protein diet. The study examined 12 healthy women who were fed an adequate-protein or a highprotein diet in a randomized crossover design. The results showed that a high-protein diet compared to an adequateprotein diet increased 24-hour satiety and also postprandial GLP-1 secretion. Taken together, these studies suggest that release of the satiety factors GLP-1 and PYY can be achieved by alteration of specific dietary constituents.

The mechanism by which high-protein diets encourage weight loss remains unknown. It is believed that nutrient sensing by the gut plays a critical role in the regulation of gut-brain signaling. The aminostatic hypothesis was proposed in 1956 and states that increased serum amino acid concentrations produced feelings of satiety. ${ }^{34}$ Since amino acids form the breakdown products of proteins, there is increasing interest in understanding how amino acids are sensed in the body. Recent advances have highlighted that different macronutrients are sensed by specific receptors on the apical surface of cells in the intestinal lumen. Moreover, specific amino acid transporters on the cell membrane have been demonstrated to participate in amino acid sensing. ${ }^{35,36}$ Of the receptors, The G-protein-coupled receptor (GPCR) family C group 6 member A (GPRC6A); the taste receptor 1 (T1R) family of T1R1, T1R2, and T1R3; and the calciumsensing receptor $(\mathrm{CaSR})$ can all sense luminal amino acids. The GPRC6A is located in the gastric G-cells and the L-cells of the small intestine and colon. It senses mainly basic amino acids and has a high affinity for L-arginine (L-Arg), L-ornithine, and L-lysine. ${ }^{37}$ The taste receptors were discovered in the oral epithelial cells and later identified on the intestinal brush cells and EEC. ${ }^{38,39}$ The T1R1 and T1R3 are selective for L-type amino acids and can sense most of them, except for tryptophan. The CaSR has also been suggested to sense amino acids and has been identified in several cells of the 
GI tract, including L-cells. ${ }^{40}$ Upon amino acid sensing, these L-cells respond by secreting gut hormones (Figure 1).

While stimulation of vagal afferents in the gut by amino acids have been shown to induce feeling of satiety, it must be noted that amino acid sensing cannot occur in the gut alone. It has been shown that subdiaphragmatic vagotomy does not diminish the ability of high-protein diets to reduce food intake. ${ }^{41}$ Amino acid sensing directly by the hypothalamus has also been suggested as a potential mechanism. Lazutkaite et $\mathrm{al}^{42}$ investigated the effect of amino acid administration into hypothalamic tanycytes, which are glial cells lining the wall of the third ventricle. The group showed that amino acids evoked $\mathrm{Ca}^{2+}$ signals in tanycytes, a marker of neuronal activity, resulting in ATP release via pannnexin 1 and CalHM1.

\section{CaSR}

The CaSR is a 7 transmembrane domain class C GPCR. ${ }^{43}$ The human CaSR consists of a 612 amino acid extracellular domain (ECD) followed by 7 transmembrane helices of 250 amino acids and finally a 216 amino acid carboxy terminal. ${ }^{44,45}$ The ECD of the CaSR has been proposed to be a Venus flytrap-like (VFT) structure that switches between "open" and "closed" conformational states upon releasing or binding agonists. ${ }^{46}$ Western analysis of the CaSR has shown the receptor exists in a dimer form ${ }^{47}$ linked by disulfide bonds through cysteine residues within the VFT. ${ }^{48}$ The CaSR binds extracellular $\mathrm{Ca}^{2+}$ over a concentration range of $0.5-10 \mathrm{mM}$. Upon binding extracellular $\mathrm{Ca}^{2+}$, intracellular $G$ proteins $G_{q^{\prime} 11}$ and $G_{i}$ are activated. Stimulation of $G$ protein $\mathrm{G}_{\mathrm{i}}$ leads to inhibition of the cyclic adenosine monophosphate pathway. Activation of $\mathrm{G}_{\mathrm{q} / 11}$ causes downstream production of inositol 1,4,5-triphosphate and diacylglycerol via phospholipase $\mathrm{C}^{49}$ This pathway results in $\mathrm{Ca}^{2+}$ release from endoplasmic reticulum stores, consequently leading to a transient peak in cytosolic $\mathrm{Ca}^{2+}$ concentration. Depletion of calcium from endoplasmic reticulum stores stimulates opening of the permeable plasma membrane $\mathrm{Ca}^{2+}$ channels, which maintains a sustained rise in cytosolic $\mathrm{Ca}^{2+}$ and ensures long-term intracellular signaling.

The CaSR was initially identified in bovine parathyroid gland $^{43}$ and found to regulate extracellular calcium homeostasis in mammals. ${ }^{44}$ Its expression in parathyroid and thyroid parafollicular $\mathrm{C}$ cells provides a sensing mechanism for the feedback regulation of parathyroid hormone (PTH) and calcitonin secretion, respectively. ${ }^{50,51}$ The CaSR is also located along the entire nephron in the kidney. Primary roles of the CaSR in the kidneys include diminishing the inhibitory effects of PTH on renal phosphate reabsorption, ${ }^{52}$ inhibiting renal calcium excretion ${ }^{53,54}$ and reducing urinary concentration. ${ }^{55}$ The CaSR is also widely expressed in tissues not typically associated with calcium homeostasis, including the brain, ${ }^{56}$ skin, ${ }^{57}$ and liver. ${ }^{58}$ Recently, the CaSR has been identified on rodent and human L-cells. ${ }^{40}$ In addition to $\mathrm{Ca}^{2+}$, a variety of divalent and trivalent cations such as $\mathrm{Mg}^{2+}$ and $\mathrm{La}^{3+}$ as well as positively-charged organic molecules like polyamines can activate the CaSR receptor. ${ }^{59-61}$ These agonists are classed as Type 1 agonists since they have their own effect on the CaSR regardless of extracellular calcium levels. Type 2 agonists modify the receptor's affinity via allosteric actions. Amino acids are type 2 agonists that can bind to the ECD of the CaSR and modulate its activity. Zhang et $\mathrm{a}^{62}$ reported that mutations in the ECD of the CaSR completely blocked the actions of L-phenylalanine (L-Phe) as a positive modulator. Mun et $\mathrm{al}^{63}$ also showed that CaSR lacking ECD exhibited impaired response to L-amino acids. A follow-up study by the group demonstrated that the binding site for amino acids may be within the VFT domain of the CaSR.

\section{CaSR as a target for amino acids}

The observation that PTH levels are elevated during protein restricted diets in humans ${ }^{64}$ suggested a link between the CaSR and amino acids. Conigrave et $\mathrm{al}^{65}$ investigated the effects of amino acids on the activity of CaSR in HEK-293 cell lines and found that specific amino acids, especially L-Phe and L-Tryptophan (L-Trp), caused intracellular $\mathrm{Ca}^{2+}$ $\left(\mathrm{Ca}^{2+}{ }_{\mathrm{i}}\right)$ mobilization. These effects were only seen when extracellular $\mathrm{Ca}^{2+}$ ions were above a threshold value between 1.0 and $1.5 \mathrm{mM}$. The CaSR also seemed to favor the natural L- rather than D-stereoisomers. Other investigators have examined the effects of amino acids on the CaSR in the GI tract. These studies suggest that the CaSR on antral G-cells and parietal cells promotes gastric acid secretion. Feng et $\mathrm{al}^{66}$ reported that gastric $\mathrm{G}$ cells in wild type mice released gastrin upon stimulation by L-Phe. However, G cells in CaSRpharmacologically inhibited or genetically-ablated $\left(\mathrm{CaSR}^{--}\right)$ mice failed to secrete gastrin. These observations suggest L-Phe and other amino acids may induce gastrin secretion via CaSR. Mace et a ${ }^{57}$ demonstrated that activation of the CaSR by L-Phe, L-Trp, L-asparagine, L-Arg and L-glutamine, resulted in GLP-1 and PYY secretion from L-cells. These responses were diminished in the absence of extracellular $\mathrm{Ca}^{2+}$ or presence of a CaSR inhibitor. Recently, Alamshah et $\mathrm{al}^{67}$ showed that L-Phe induces GLP-1 secretion from STC-1 cells, an L-cell in vitro model, and also primary L-cells. Moreover, the group administered L-Phe orally to rats and mice. The authors reported an acute reduction in food intake 
in both rats and mice, and a chronic reduction in food intake and body weight in diet-induced obese mice. This affect was also seen when L-Phe was given via the ileum. Pharmacological blockade of the CaSR attenuated the anorectic affect of intra-ileal L-Phe in rats and also L-Phe induced GLP-1 secretion from STC-1 and primary L-cells. Together, these observations suggest amino acids act via the CaSR on L-cells to drive gut hormone release, and that this process requires extracellular $\mathrm{Ca}^{2+}$ concentration above a certain threshold. Whilst STC-1 cells provide a useful screening platform for analyzing mechanisms that mediate gut hormone secretion in vitro, variations have been reported regarding the expression of CaSR on these cells. Young et $\mathrm{al}^{35}$ aimed to localize the CaSR on STC-1 cells by using antibodies targeting the ECD of the receptor. They found limited CaSR immunoreactivity on the cell surface of STC-1 cells. Conversely, L-cells from human colonic mucosa have been shown to highly express the CaSR. ${ }^{68}$ This variation suggests that expression pattern of CaSR on STC-1 cells may not reflect endogenous expression. Moreover, gut hormone secretion levels from STC-1 cells have shown inconsistencies for the same metabolite.

\section{Caveats of a high-protein diet and targeting the CaSR}

The CaSR is expressed on both luminal and vascular surfaces of EEC. ${ }^{40}$ It is unknown on which surface the CaSR physiologically senses amino acids. In vivo, it may be possible to employ either intravascular or luminal administration of amino acids and measure GLP-1 secretion in response. ${ }^{69}$ If amino acids are sensed by CaSR from the vascular surface, there is a possibility they may reach CaSR in other sites via circulation and disrupt calcium homeostasis. Furthermore, there are growing concerns that a high-protein diet reduces lifespan. While the evidence for this has been primarily in insects, ${ }^{70}$ it must be considered whether mimicking the actions of these diets at specific receptors can have toxic side effects.

A number of literature reviews suggest that low-protein diets, particularly branched-chain amino acids (BCAA), which include leucine, isoleucine and valine, may be metabolically beneficial. Newgard et $\mathrm{al}^{71}$ first demonstrated that components consisting of BCAAs and BCAA byproducts were strongly associated with obesity. They showed that these components were positively associated with the homeostasis model assessment-insulin resistance index $(r=0.58, P<0.001)$. It has been established that gastric bypass surgery leads to weight loss and better glycemic control. Lafferere et $\mathrm{al}^{72}$ reported that levels of BCAAs significantly dropped after gastric bypass surgery and was related to insulin resistance.
The authors suggest that that the improved glucose levels following gastric bypass surgery may be due to changes in BCAAs.

Recently, Fontana et $\mathrm{al}^{73}$ described the metabolic benefits of a protein-restricted diet in rodents. The authors reported that feeding mice a diet restricted in BCAA was sufficient to improve glucose tolerance and body composition. This study was further supported by Cummings et $\mathrm{al}^{74}$ who investigated the effects of reducing BCAA in diet-induced obese mice with pre-existing metabolic syndrome. The group found that dietary BCAAs were quick at reversing the diet-induced obesity and improving glucoregulatory control. The study further demonstrated that mice eating an unhealthy highsugar Western diet with decreased levels of BCAAs lost weight and fat rapidly. However, it is not certain that these observations will be replicated in human subjects. Moreover, Sluijs et $\mathrm{al}^{75}$ conducted a large prospective study where they studied the relationship between the incidence of diabetes and protein consumption. The group analyzed 38,094 participants and reported that the incidence of diabetes increased with a higher protein intake.

\section{Conclusion}

Nutrient sensing by receptors on L-cells has opened new avenues for pharmacological approaches to control the obesity epidemic. Of the receptors, there is growing evidence to suggest that CaSR may be implicated in amino acid-induced satiation. Although our understanding of the receptors implicated in this process has advanced, we are still in the preliminary stages of understanding how these systems regulate energy homeostasis and how they might be exploited therapeutically.

\section{Disclosure}

Utkarsh Ojha is a medical student at Imperial College London holding a Medical Sciences BSc in Endocrinology. The author reports no other conflicts of interest in this work.

\section{References}

1. World Health Organization. WHO: Obesity and Overweight. Available from: http://www.who.int/mediacentre/factsheets/fs311/en/. Accessed April 23, 2017.

2. World Health Organization. WHO: The Top 10 Causes of Death. Available from: http://www.who.int/mediacentre/factsheets/fs310/en/. Accessed April 23, 2017.

3. National Institute for Health and Care Excellence. Obesity: Identification, Assessment and Management. London: National Institute for Health and Care Excellence; 2014.

4. Pontiroli A, Morabito A. Long-term prevention of mortality in morbid obesity through bariatric surgery. A systematic review and meta-analysis of trials performed with gastric banding and gastric bypass. Ann Surg. 2011;253(3):484-487. 
5. Christensen R, Kristensen P, Bartels E, Bliddal H, Astrup A. Efficacy and safety of the weight-loss drug rimonabant: a meta-analysis of randomised trials. Lancet. 2007;370(9600):1706-1713.

6. Abenhaim L, Moride Y, Brenot F, et al. Appetite-suppressant drugs and the risk of primary pulmonary hypertension. International Primary Pulmonary Hypertension Study Group. N Engl J Med. 1996;335(9): 609-616.

7. James WP, Caterson ID, Coutinho W, et al; SCOUT Investigators. Effect of sibutramine on cardiovascular outcomes in overweight and obese subjects. N Engl J Med. 2010;363(10):905-917.

8. Kanstrup C. Obesity Market Update and Saxenda Performance. Denmark: Novo Nordisk; 2015.

9. Hollywood A, Ogden J. Taking orlistat: predicting weight loss over 6 months. Int J Obes. 2011;2011:806896.

10. Aiken K, Kisslinger J, Roth K. Immunohistochemical studies indicate multiple enteroendocrine cell differentiation pathways in the mouse proximal small intestine. Dev Dyn. 1994;201(1):63-70.

11. Habib A, Richards P, Rogers G, Reimann F, Gribble F. Co-localisation and secretion of glucagon-like peptide 1 and peptide $Y Y$ from primary cultured human L cells. Diabetologia. 2013;56(6):1413-1416.

12. Grandt D, Schimiczek M, Struk K, et al. Characterization of two forms of peptide YY, PYY (1-36) and PYY (3-36), in the rabbit. Peptides. 1994;15(5):815-820.

13. Grandt D, Schimiczek M, Beglinger C, et al. Two molecular forms of peptide YY (PYY) are abundant in human blood: characterization of a radioimmunoassay recognizing PYY 1-36 and PYY 3-36. Regul Pept. 1994;51(2):151-159.

14. Meeran K, O'Shea D, Edwards CM, et al. Repeated intracerebroventricular administration of glucagon-like peptide-1-(7-36) amide or exendin-(9-39) alters body weight in the rat. Endocrinology. 1999;140(1):244-250.

15. Batterham RL, Cowley MA, Small CJ, et al. Gut hormone PYY3-36 physiologically inhibits food intake. Nature. 2002;418(6898):650-654.

16. Jobst E, Enriori P, Cowley M. The electrophysiology of feeding circuits. Trends Endocrinol Metab. 2004;15(10):488-499.

17. Lin H, Zhao X, Wang L, Wong H. Fat-induced ileal brake in the dog depends on peptide YY. Gastroenterology. 1996;110(5):1491-1495.

18. Wen J, Phillips SF, Sarr MG, Kost LJ, Holst JJ. PYY and GLP-1 contribute to feedback inhibition from the canine ileum and colon. Am J Physiol. 1995;26(6):945-952.

19. Eissele R, Göke R, Willemer S, et al. Glucagon-like peptide-1 cells in the gastrointestinal tract and pancreas of rat, pig and man. Eur J Clin Invest. 1992;22(4):283-291.

20. Todd J, Edwards C, Ghatei M, Mather H, Bloom S. Subcutaneous glucagon-like peptide-1 improves postprandial glycaemic control over a 3 -week period in patients with early type 2 diabetes. Clin Sci. 1998;95(3):325-329.

21. Toft-Nielsen M, Madsbad S, Holst J. Continuous subcutaneous infusion of glucagon-like peptide 1 lowers plasma glucose and reduces appetite in type 2 diabetic patients. Diabetes Care. 1999;22(7):1137-1143.

22. Sloth B, Davidsen L, Holst J, Flint A, Astrup A. Effect of subcutaneous injections of PYY1-36 and PYY3-36 on appetite, ad libitum energy intake, and plasma free fatty acid concentration in obese males. $\mathrm{Am} \mathrm{J}$ Physiol Endocrinol Metab. 2007;293(2):604-609.

23. Chandarana K, Gelegen C, Karra E, et al. Diet and gastrointestinal bypass-induced weight loss. Diabetes. 2011;60(3):810-818.

24. Dar MS, Chapman WH 3rd, Pender JR, et al. GLP-1 response to a mixed meal: what happens 10 years after Roux-en-Y gastric bypass (RYGB)? Obes Surg. 2012;22(7):1077-1083.

25. le Roux CW, Aylwin SJ, Batterham RL, et al. Gut hormone profiles following bariatric surgery favor an anorectic state, facilitate weight loss, and improve metabolic parameters. Ann Surg. 2006;243(1):108-114.

26. European Medicines Agency. EPAR summary for the public: Saxenda. European Medicines Agency; 2015. Available from: http://www.ema. europa.eu/docs/en_GB/document_library/EPAR_-_Summary_for_the_ public/human/003780/WC500185789.pdf. Accessed April 28, 2017.
27. U.S. Department of Health and Human Services. FDA Approves Weight-Management Drug Sexenda. U.S. Department of Health and Human Services; 2014. Available from: https://www.fda.gov/ newsevents/newsroom/PressAnnouncements/default.htm. Accessed April 28, 2017.

28. Skov A, Toubro S, Rønn B, Holm L, Astrup A. Randomized trial on protein vs carbohydrate in ad libitum fat reduced diet for the treatment of obesity. Int J Obes. 1999;23(5):528-536.

29. Weigle DS, Breen PA, Matthys CC, et al. A high-protein diet induces sustained reductions in appetite, ad libitum caloric intake, and body weight despite compensatory changes in diurnal plasma leptin and ghrelin concentrations. Am J Clin Nutr. 2005;82(1):41-48.

30. Layman DK, Evans EM, Erickson D, et al. A moderate-protein diet produces sustained weight loss and long-term changes in body composition and blood lipids in obese adults. J Nutr. 2009;139(3):514-521.

31. Westerterp-Plantenga M, Lejeune M, Nijs I, van Ooijen M, Kovacs E. High protein intake sustains weight maintenance after body weight loss in humans. Int J Obes. 2004;28(1):57-64.

32. Batterham RL, Heffron $H$, Kapoor S, et al. Critical role for peptide YY in protein-mediated satiation and body-weight regulation. Cell Metab. 2006;4(3):223-233.

33. Lejeune M, Kovacs E, Westerterp-Plantenga M. Additional protein intake limits weight regain after weight loss in humans. Br J Nutr. 2005;93(02):281.

34. Mellinkoff SM, Frankland M, Boyle D, Greipel M. Relationship between serum amino acid concentration and fluctuations in appetite. $J$ Appl Physiol. 1956;8(5):535-538.

35. Young S, Rey O, Sternini C, Rozengurt E. Amino acid sensing by enteroendocrine STC-1 cells: role of the Na+-coupled neutral amino acid transporter 2. Am J Physiol Cell Physiol. 2010;298(6):1401-1413.

36. Tolhurst G, Zheng Y, Parker H, Habib A, Reimann F, Gribble F. Glutamine triggers and potentiates glucagon-like peptide- 1 secretion by raising cytosolic Ca2+and cAMP. Endocrinology. 2011;152(2):405-413.

37. Wellendorph P, Hansen KB, Balsgaard A, Greenwood JR, Egebjerg J, Bräuner-Osborne H. Deorphanization of GPRC6A: a promiscuous L-alpha-amino acid receptor with preference for basic amino acids. Mol Pharmacol. 2004;67(3):589-597.

38. Daly K, Al-Rammahi M, Moran A, Marcello M, Ninomiya Y, ShiraziBeechey S. Sensing of amino acids by the gut-expressed taste receptor T1R1-T1R3 stimulates CCK secretion. Am J Physiol Gastrointest Liver Physiol. 2012;304(3):271-282.

39. Dyer J, Salmon K, Zibrik L, Shirazi-Beechey S. Expression of sweet taste receptors of the T1R family in the intestinal tract and enteroendocrine cells. Biochem Soc Trans. 2005;33(1):302-305.

40. Mace O, Schindler M, Patel S. The regulation of K- and L-cell activity by GLUT2 and the calcium-sensing receptor CasR in rat small intestine. J Physiol. 2012;590(12):2917-2936.

41. L'Heureux-Bouron D, Tomé D, Rampin O, Even PC, Larue-Achagiotis C, Fromentin G. Total subdiaphragmatic vagotomy does not suppress high protein diet-induced food intake depression in rats. $J$ Nutr. 2003;133(8):2639-2642.

42. Lazutkaite G, Soldà A, Lossow K, Meyerhof W, Dale N. Amino acid sensing in hypothalamic tanycytes via umami taste receptors. Mol Metab. 2017;6(11):1480-1492.

43. Brown EM, Gamba G, Riccardi D, et al. Cloning and characterization of an extracellular $\mathrm{Ca}(2+)$-sensing receptor from bovine parathyroid. Nature. 1993;366(6455):575-580.

44. Garrett JE, Capuano IV, Hammerland LG, et al. Molecular cloning and functional expression of human parathyroid calcium receptor cDNAs. J Biol Chem. 1995;270(21):12919-12925.

45. Aida K, Koishi S, Tawata M, Onaya T. Molecular cloning of a putative $\mathrm{Ca}(2+)$-sensing receptor cDNA from human kidney. Biochem Biophys Res Commun. 1995;214(2):524-529.

46. Silve C, Petrel C, Leroy C, et al. Delineating a Ca2+ binding pocket within the venus flytrap module of the human calcium-sensing receptor. J Biol Chem. 2005;280(45):37917-37923. 
47. Bai M, Trivedi S, Brown E. Dimerization of the extracellular calciumsensing receptor $(\mathrm{CaR})$ on the cell surface of CaR-transfected HEK293 cells. J Biol Chem. 1998;273(36):23605-23610.

48. Zhang Z, Sun S, Quinn S, Brown E, Bai M. The extracellular calciumsensing receptor dimerizes through multiple types of intermolecular interactions. J Biol Chem. 2000;276(7):5316-5322.

49. Kifor O, Diaz R, Butters R, Brown E. The Ca2+-sensing receptor $(\mathrm{CaR})$ activates phospholipases $\mathrm{C}, \mathrm{A} 2$, and $\mathrm{D}$ in bovine parathyroid and $\mathrm{CaR}$ transfected, human embryonic kidney (HEK293) Cells. J Bone Miner Res. 1997;12(5):715-725.

50. Scherübl H, Kleppisch T, Zink A, Raue F, Krautwurst D, Hescheler J. Major role of dihydropyridine-sensitive $\mathrm{Ca} 2+$ channels in $\mathrm{Ca}(2+)$ induced calcitonin secretion. Am J Physiol. 1993;264(3):354-360.

51. McGehee DS, Aldersberg M, Liu KP, Hsuing S, Heath MJ, Tamir H. Mechanism of extracellular $\mathrm{Ca} 2+$ receptor-stimulated hormone release from sheep thyroid parafollicular cells. J Physiol. 1997;502(Pt 1):31-44.

52. Ba J, Brown D, Friedman P. Calcium-sensing receptor regulation of PTH-inhibitable proximal tubule phosphate transport. Am J Physiol Renal Physiol. 2003;285(6):1233-1243.

53. Chattopadhyay N, Baum M, Bai M, et al. Ontogeny of the extracellular calcium-sensing receptor in rat kidney. Am J Physiol. 1996;3(Pt 2):736-743.

54. Attie MF, Gill JR Jr, Stock JL, et al. Urinary calcium excretion in familial hypocalciuric hypercalcemia. Persistence of relative hypocalciuria after induction of hypoparathyroidism. J Clin Invest. 1983;72(2):667-676.

55. Sands J, Naruse M, Baum M, et al. Apical extracellular calcium/ polyvalent cation-sensing receptor regulates vasopressin-elicited water permeability in rat kidney inner medullary collecting duct. J Clin Invest 1997;99(6):1399-1405.

56. Chattopadhyay N, Légrádi G, Bai M, et al. Calcium-sensing receptor in the rat hippocampus: a developmental study. Dev Brain Res. 1997;100(1):13-21.

57. Oda Y, Tu C, Pillai S, Bikle D. The calcium sensing receptor and its alternatively spliced form in keratinocyte differentiation. J Biol Chem. 1998;273(36):23344-23352.

58. Canaff L, Petit J, Kisiel M, Watson P, Gascon-Barre M, Hendy G. Extracellular calcium-sensing receptor is expressed in rat hepatocytes. Coupling to intracellular calcium mobilization and stimulation of bile flow. J Biol Chem. 2000;276(6):4070-4079.

59. Miki H, Maercklein PB, Fitzpatrick LA. Effect of magnesium on parathyroid cells: evidence for two sensing receptors or two intracellular pathways? Am J Physiol. 1997;272:1-6.

60. Hebert SC, Brown EM, Harris HW. Role of the Ca2+-sensing receptor in divalent mineral ion homeostasis. J Exp Biol. 1997;200(Pt 2):295-302.

61. Quinn SJ, Ye CP, Diaz R, et al. The Ca2+-sensing receptor: a target for polyamines. Am J Physiol. 1997;273(4):1315-1323.
62. Zhang C, Huang Y, Jiang Y, et al. Identification of an L-phenylalanine binding site enhancing the cooperative responses of the calcium-sensing receptor to calcium. J Biol Chem. 2014;289(8):5296-5309.

63. Mun HC, Culverston EL, Franks AH, Collyer CA, Clifton-Bligh RJ, Conigrave AD. A double mutation in the extracellular $\mathrm{Ca} 2+-$ sensing receptor's venus flytrap domain that selectively disables L-amino acid sensing. J Biol Chem. 2005;280(32):29067-29072.

64. Kerstetter JE, Caseria DM, Mitnick ME, et al. Increased circulating concentrations of parathyroid hormone in healthy, young women consuming a protein-restricted diet. Am J Clin Nutr. 1997;66(5):1188-1196.

65. Conigrave A, Franks A, Brown E, Quinn S. L-Amino acid sensing by the calcium-sensing receptor: a general mechanism for coupling protein and calcium metabolism? Eur J Clin Nutr. 2002;56(11):1072-1080.

66. Feng J, Petersen CD, Coy DH, et al. Calcium-sensing receptor is a physiologic multimodal chemosensor regulating gastric G-cell growth and gastrin secretion. Proc Natl Acad Sci. 2010;107(41):17791-17796.

67. Alamshah A, Spreckley E, Norton M, et al. 1-phenylalanine modulates gut hormone release and glucose tolerance, and suppresses food intake through the calcium-sensing receptor in rodents. Int J Obes (Lond). 2017;41(11):1693-1701.

68. Sheinin Y, Kállay E, Wrba F, Kriwanek S, Peterlik M, Cross H. Immunocytochemical localization of the extracellular calcium-sensing receptor in normal and malignant human large intestinal mucosa. $J$ Histochemistry. 2000;48(5):595-601.

69. Christensen LW, Kuhre RE, Janus C, Svendsen B, Holst JJ. Vascular, but not luminal, activation of FFAR1 (GPR40) stimulates GLP-1 secretion from isolated perfused rat small intestine. Physiol Rep. 2015;3(9):1-13.

70. Lee KP, Simpson SJ, Clissold FJ, et al. Lifespan and reproduction in Drosophila: new insights from nutritional geometry. Proc Natl Acad Sci. 2008;105(7):2498-2503.

71. Newgard CB, An J, Bain JR, et al. A branched chain amino acid-related metabolic signature that differentiates obese and lean humans and contributes to insulin resistance. Cell Metab. 2009;9(4):311-326.

72. Laferrère B, Reilly D, Arias S, et al. Differential metabolic impact of gastric bypass surgery versus dietary intervention in obese diabetic subjects despite identical weight loss. Sci Transl Med. 2011;3(80):80re2.

73. Fontana L, Cummings NE, Arriola Apelo SI, et al. Decreased consumption of branched chain amino acids improves metabolic health. Cell Rep. 2016;16(2):520-530.

74. Cummings N, Williams E, Kasza I, et al. Restoration of metabolic health by decreased consumption of branched-chain amino acids. J Physiol. Epub 2017 Dec 9.

75. Sluijs I, Beulens JWJ, van der ADL, Spijkerman AMW, Grobbee DE, van der Schouw YT. Dietary intake of total, animal, and vegetable protein and risk of type 2 diabetes in the European Prospective Investigation into Cancer and Nutrition (EPIC)-NL Study. Diabetes Care. 2010;33(1):43-48.

Diabetes, Metabolic Syndrome and Obesity: Targets and Therapy

\section{Publish your work in this journal}

Diabetes, Metabolic Syndrome and Obesity: Targets and Therapy is an international, peer-reviewed open-access journal committed to the rapid publication of the latest laboratory and clinical findings in the fields of diabetes, metabolic syndrome and obesity research. Original research, review, case reports, hypothesis formation, expert opinion and commentaries are all considered for publication. The manuscript management system is completely online and includes a very quick and fair peer-review system, which is all easy to use. Visit http://www.dovepress.com/testimonials.php to read real quotes from published authors. 